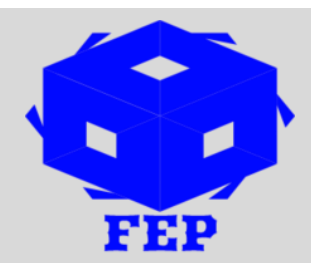

\title{
HISTOLOGY OF A XEROPHYTIC LEAFLET: CYCAS CIRCINALIS AND CYCAS REVOLUTA (CYCADACEAE)
}

\author{
Poonam Sethi ${ }^{1}$, Himanshu Gupta ${ }^{2}$, Ellakiya ${ }^{3}$, Bharat Kumar ${ }^{4}$ \\ 1,2,3,4 Assistant Professor, Guru Nanak College, (Autonomous), Chennai, India
}

*Corresponding Author: Poonam Sethi.

Corresponding Author Email: poonam123.73@ rediffmail.com

Article Received: 17-09-19

Accepted: 30-12-19

Published: $31-01-20$

Licensing Details: Author retains the right of this article. The article is distributed under the terms of the Creative Commons Attribution-Non Commercial 4.0 License (http://www.creativecommons.org/licences/by-nc/4.0/) which permits non-commercial use, reproduction and distribution of the work without further permission provided the original work is attributed as specified on the Journal open access page.

\begin{abstract}
Cycas, a primitive gymnosperm is currently facing extinction since the stem produces a starch like substance called sago, also called as sago palm. Cycads are xerophytic as they require scanty water even more drought tolerant. This study compares the leaflet micromorphological characters as a taxonomic tool to independently identify two Indian Cycad species. Cycas.circinalis and Cycas.revoluta. Anatomical investigations were carried out and presented. Phytochemicals and physicochemical analysis of powdered leaflet was also carried out.
\end{abstract}

Keywords: Anatomy, Cycas, Leaflet, Phytochemical, Sago Palm, ,Taxonomic Tool, Xerophytic.

\section{INTRODUCTION}

Medicinal plants are remedies of human diseases as they contain components of therapeutic value. An increasing interest in herbal remedies has been observed in several parts of the world and many of the herbal remedies have been incorporated into orthodox medicinal plant practice. Diseases such as malaria, epilepsy, infantile convulsion, diarrhoea, dysentery, fungal and bacterial infections have been managed by traditionally using of medicinal plant (Sofowora, 1996). India has the oldest, richest and most diverse cultural traditions associated with the use of plants as medicines. Several bioactive constituents have been isolated and studied for pharmacological activity. During the last two decades, pharmacological and chemical researches all over the world in an effort to discover much more potent drugs, rather, a few new drugs. 
Cycas is the only currently known genus of the family Cycadaceae, order Cycadales. Cycas revoluta Thunb is the most widespread species of the genus Cycas and is known as sago Cycas or king sago palm while C. circinalis L is known as queen sago palm. Generally, Cycas is also designated as Living Fossil (Lindstrom \& Hill, 2007). The plant takes several years to grow, sexual reproduction takes place after 10 years. This genus is native to eastern and south eastern Asia and is cultivated in many tropical and subtropical areas for ornamental purposes.

The Chinese utilize the seeds of C. revoluta as an antirheumatic, expectorant, and tonic. The terminal shoots are utilized as an astringent and diuretic (Botha, Naude, \& Swan, 1991). The very young leaves are edible and the juice of tender leaves is useful for the treatment of flatulence and vomiting (Muller-Esneault \& Susan, 2009). It was also reported that a tincture of C. revoluta leaves contains inhibitors efficacious in treating estrogen-dependent carcinoma (Knight \& Dorman, 1997). Recently in the past twenty years, many of the plant species have been documented pharmacologically which are endowed in phytochemicals with marked activity on human pathogenic bacterial strains (Kumar, Kumar Selvaraj, 2013). All parts of the plant are toxic; however, the seeds contain the highest level of the toxin cycasin. Cycasin causes gastrointestinal irritation, and in high enough doses, leads to liver failure (Manoj, Mourya, Prakash, Swami, Singh, \& Mathur, 2011).

\section{MATERIALS AND METHOD}

The whole plant was collected from Guru Nanak College campus, Chennai of Tamilnadu, India identified by botanist of CSMDRIA Chennai.(Figure I) Microscopical characters were studied as in the manual (Trease \& Evans, 1997)

Ten grams of the leaf powder was extracted with $100 \mathrm{ml}$ distilled water and ethanol later kept for 48 hours. The samples were filtered and the filtrate was dried in a lyophilizer. Different extracts were screened for physicochemical (AOAC, 1990) and the presence of phytocompounds such as phenols, flavonoids, tannin, saponin, alkaloids and steroid by using standard protocols AOAC and Harbone.

\section{i)BOTANICAL DESCRIPTION}

\section{RESULTS}

Cycads are an ancient group of naked seed plants with a crown of large compound leaves and a stout trunk. Cycads are dioecious, female plant produces the seeds, and the male produces cones with pollen in them. The Sago Palm is not a palm, but a cycad. The leaves are bright green, semiglossy, 150-250 cm long, flat (not keeled) in section (opposing leaflets inserted at $180^{\circ}$ on rachis), with 170 leaflets, tomentum shedding as leaf expands. The Queen Sago does not branch whereas the King Sago, Cycas revoluta, creates many heads branching off from the main trunk and also from sprouts at ground level. Male Sago plants develop a cone approximately $30 \mathrm{~cm}$ tall coming from the center of the top. The cone is white or yellow, rounded and produces abundant pollen. The seeds are quite large and are brown or yellow and are displayed on the feather-like seed-bearing leaves. The seeds have a spongy layer that allows them to float on water. As a slow growing plant, the seed can take from 6-18 months 
to germinate. Queen Sago is pollinated by a species of weevil, which finds protection in the plant's cone and seed-bearing leaves.

\section{ii)MICROSCOPICAL CHARACTERS}

The anatomical characters are listed in the Table IV where the anatomical features are compared .

\section{iii)PHYSICOCHEMICAL CHARACTERS AND PHYTOCHEMICAL COMPONENTS}

The physicochemical and phytochemical characters are given in tabular column I, II and III.

\section{CONCLUSION}

The above parameters help in identifying the species and to establish the authenticity of the plants and can possibly help to differentiate the drug from its other adulterants.

\section{TABLES}

Table 1: Physicochemical Analysis of Powdered Leaflet

\begin{tabular}{|c|l|c|c|}
\hline S. No & \multicolumn{1}{|c|}{ Parameters } & $\begin{array}{c}\text { C.circinalis Values obtained } \\
(\boldsymbol{\%} \mathbf{w} / \mathbf{w})\end{array}$ & $\begin{array}{c}\text { C.revoluta Values obtained } \\
(\boldsymbol{\%} \mathbf{w} / \mathbf{w})\end{array}$ \\
\hline 1 & Total ash value & 8.12 & 0.64 \\
\hline 2 & Acid insoluble ash & 5.2 & 8.5 \\
\hline 3 & Water soluble ash & 8.4 & 2.8 \\
\hline 4 & Moisture content & 5.9 & 11.33 \\
\hline 5 & Crude fiber content & 9.76 & 0.94 \\
\hline 6 & Alcohol soluble extractive & 5.6 & 8.74 \\
\hline 7 & Water soluble extractive & 8.6 & 3.2 \\
\hline 8 & Foreign organic matter & 6.4 & 9.33 \\
\hline
\end{tabular}

Table 2: Phytochemical Analysis of Powdered Leaflet of Cycas Circinalis

\begin{tabular}{|l|c|c|}
\hline Phytochemical constituent & AQUEOUS & ETHANOLIC \\
\hline Alkaloids & + & + \\
\hline Tannin & - & + \\
\hline Saponin & - & + \\
\hline Flavonoid & + & + \\
\hline Glycosides & + & - \\
\hline Phenol & - & + \\
\hline Carbohydrates & + & + \\
\hline Quinone & - & - \\
\hline Resin & - & - \\
\hline Oil & - & - \\
\hline Lignin & + & + \\
\hline Protein & - & + \\
\hline
\end{tabular}


Table 3: Phytochemical Analysis of Powdered Leaflet of Cycas Revoluta

\begin{tabular}{|l|c|c|}
\hline Phytochemical constituent & AQUEOUS & ETHANOLIC \\
\hline Alkaloids & + & + \\
\hline Tannin & - & + \\
\hline Saponin & - & - \\
\hline Flavonoid & + & + \\
\hline Glycosides & + & + \\
\hline Phenol & - & + \\
\hline Carbohydrates & + & + \\
\hline Quinone & - & - \\
\hline Resin & - & - \\
\hline Oil & - & - \\
\hline Lignin & - & + \\
\hline Protein & + & + \\
\hline
\end{tabular}

Table 4: Anatomical Characters of Leaflets

\begin{tabular}{|c|c|c|}
\hline $\begin{array}{l}\text { Anatomical } \\
\text { Character }\end{array}$ & Cycas circinalis & Cycas revoluta \\
\hline Epidermis & $\begin{array}{l}\text { Epidermis single } \\
\text { cuticle and deposition of lignin and } \\
\text { waxy coating.Cells of epidermis } \\
\text { rounded. }\end{array}$ & $\begin{array}{l}\text { Epidermis single layered and cuticle } \\
\text { present .No coating lignin and waxy } \\
\text { substances. .Cells of epidermis } \\
\text { isodiametric. }\end{array}$ \\
\hline Stomata & Stomata are many & Stomata are few but sunken \\
\hline Hypodermis & $\begin{array}{l}\text { Hypodermis } 2 \text { layered below upper } \\
\text { epidermis and } 2 \text { layered above lower } \\
\text { epidermis. }\end{array}$ & $\begin{array}{l}\text { Hypodermis } 4 \text { layered sclerenchymatous } \\
\text { below upper epidermis and } 3 \text { layered } \\
\text { above lower epidermis. }\end{array}$ \\
\hline $\begin{array}{l}\text { Mesophyll } \\
\text { tissue }\end{array}$ & $\begin{array}{l}\text { Palisade parenchyma single layered } \\
\text { elongated cells. } \\
\text { Spongy parenchyma } 2 \text { layered. }\end{array}$ & $\begin{array}{l}\text { Palisade parenchyma double layered. } \\
\text { Spongy parenchyma } 4 \text { layered. }\end{array}$ \\
\hline Stone cells & Stone cells are absent. & $\begin{array}{l}\text { Stone cells are present as patches in } \\
\text { mesophyll. }\end{array}$ \\
\hline $\begin{array}{l}\text { Transfusion } \\
\text { tissue }\end{array}$ & Transfusion tissue 4 layered. & $\begin{array}{l}\text { Transfusion tissue abundant nearly } 6 \\
\text { layered. }\end{array}$ \\
\hline Bundle sheath & $\begin{array}{l}\text { Bundle sheath single layered } \\
\text { sclerenchymatous and continuous. }\end{array}$ & $\begin{array}{l}\text { Bundle sheath } 2 \text { layered an broken } \\
\text { patches of sclerenchymatous. }\end{array}$ \\
\hline Xylem & $\begin{array}{l}\text { Centripetal xylem ' } V \text { ' shaped more of } \\
\text { metaxylem and centrifugal } \\
\text { protocylem points. }\end{array}$ & $\begin{array}{l}\text { Equal number of metaxylem and } \\
\text { protoxylem. } 6 \text { protoxylem points. }\end{array}$ \\
\hline Phloem & Phloem limited. & Phloem abundant. \\
\hline
\end{tabular}




\section{FIGURES}
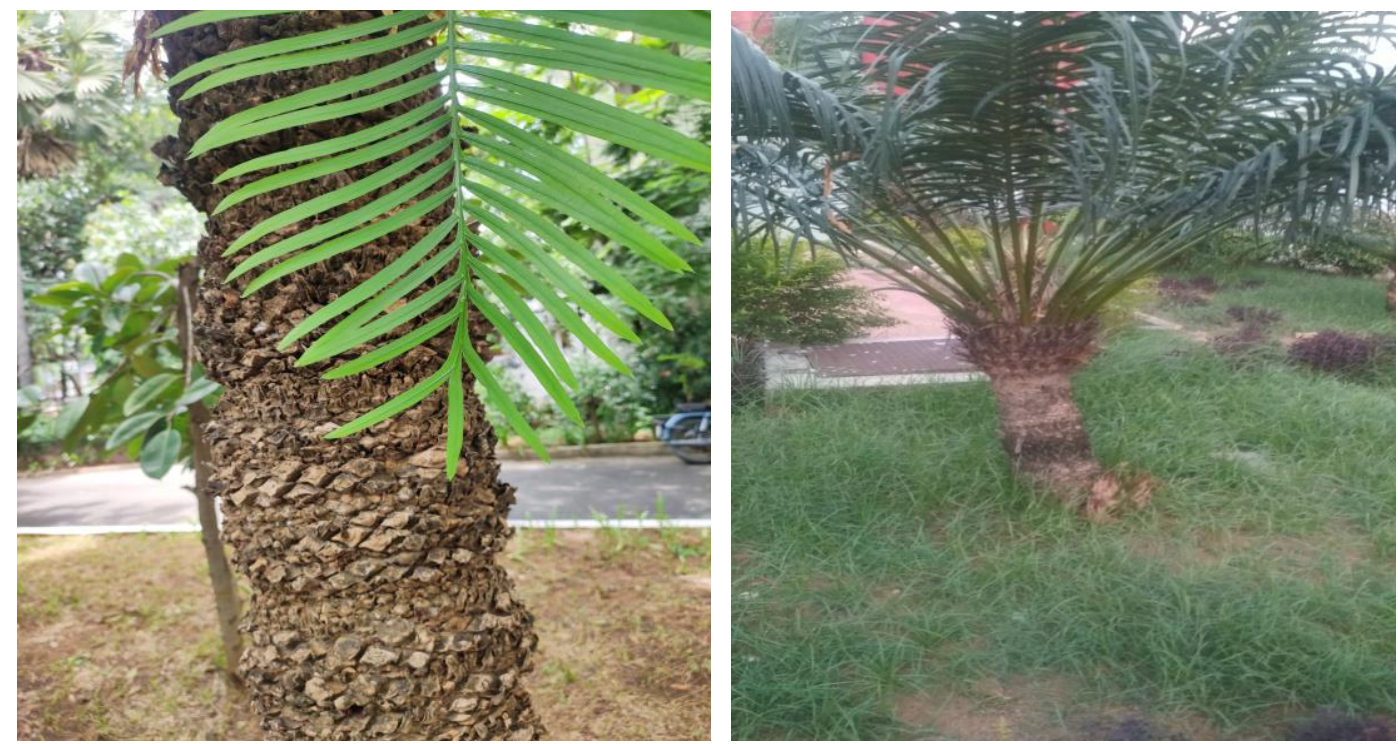

Figure 1: CYCAS CIRCINALIS CYCAS REVOLUTA

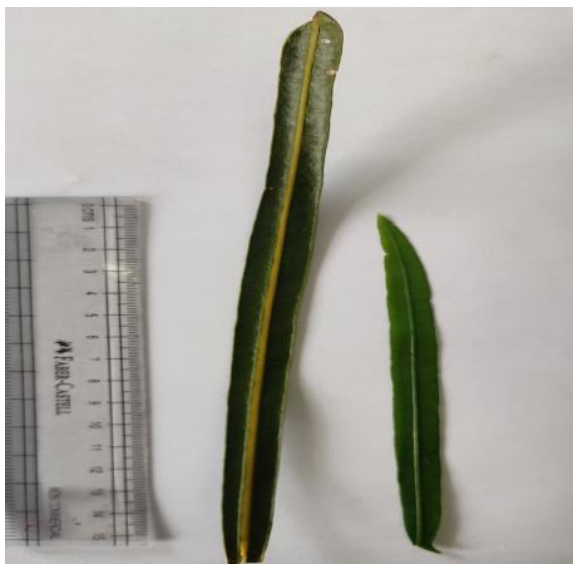

Figure 2: Leaflet of Cycas Circinalis and revoluta 


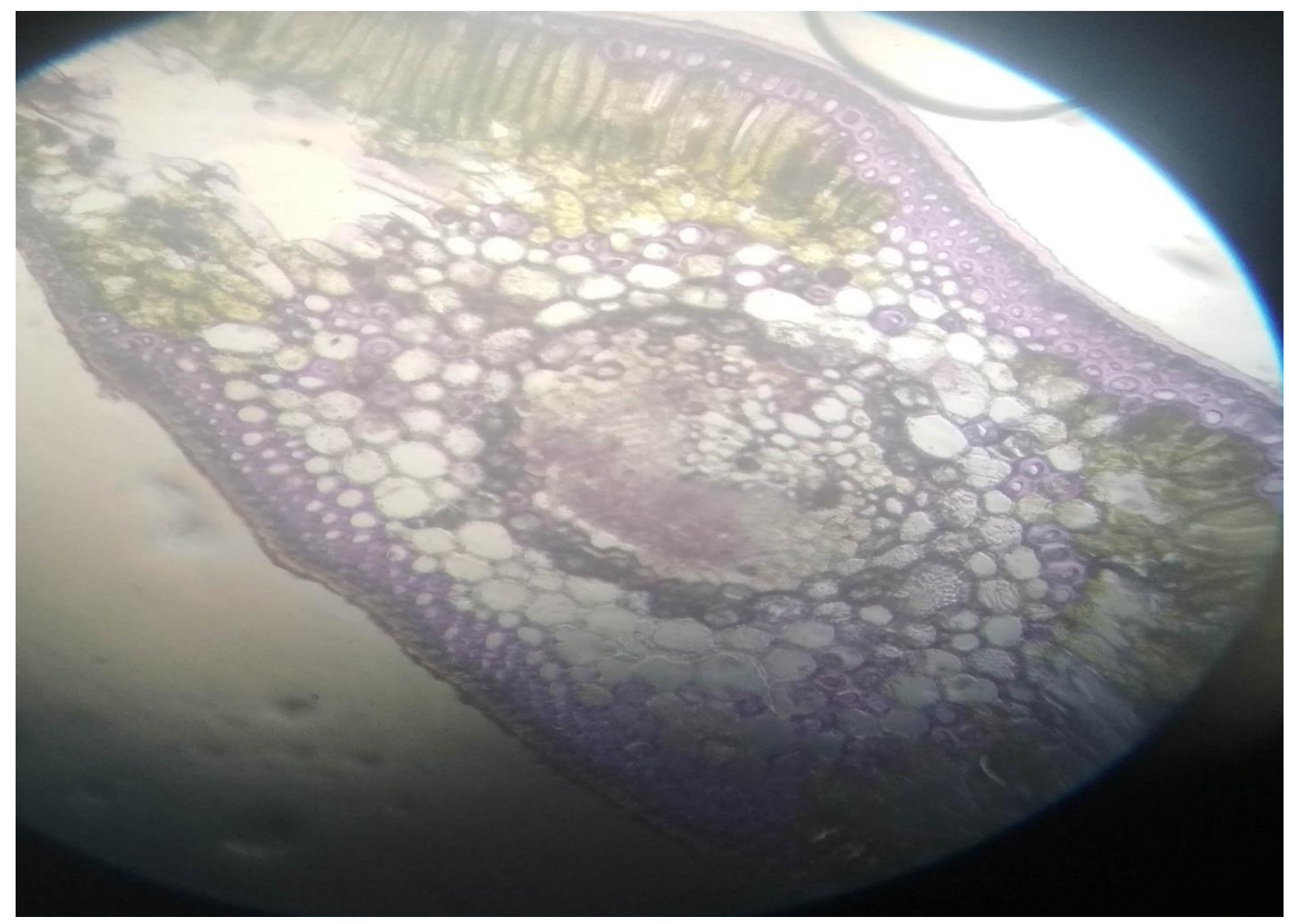

\section{CYCAS CIRCINALIS}

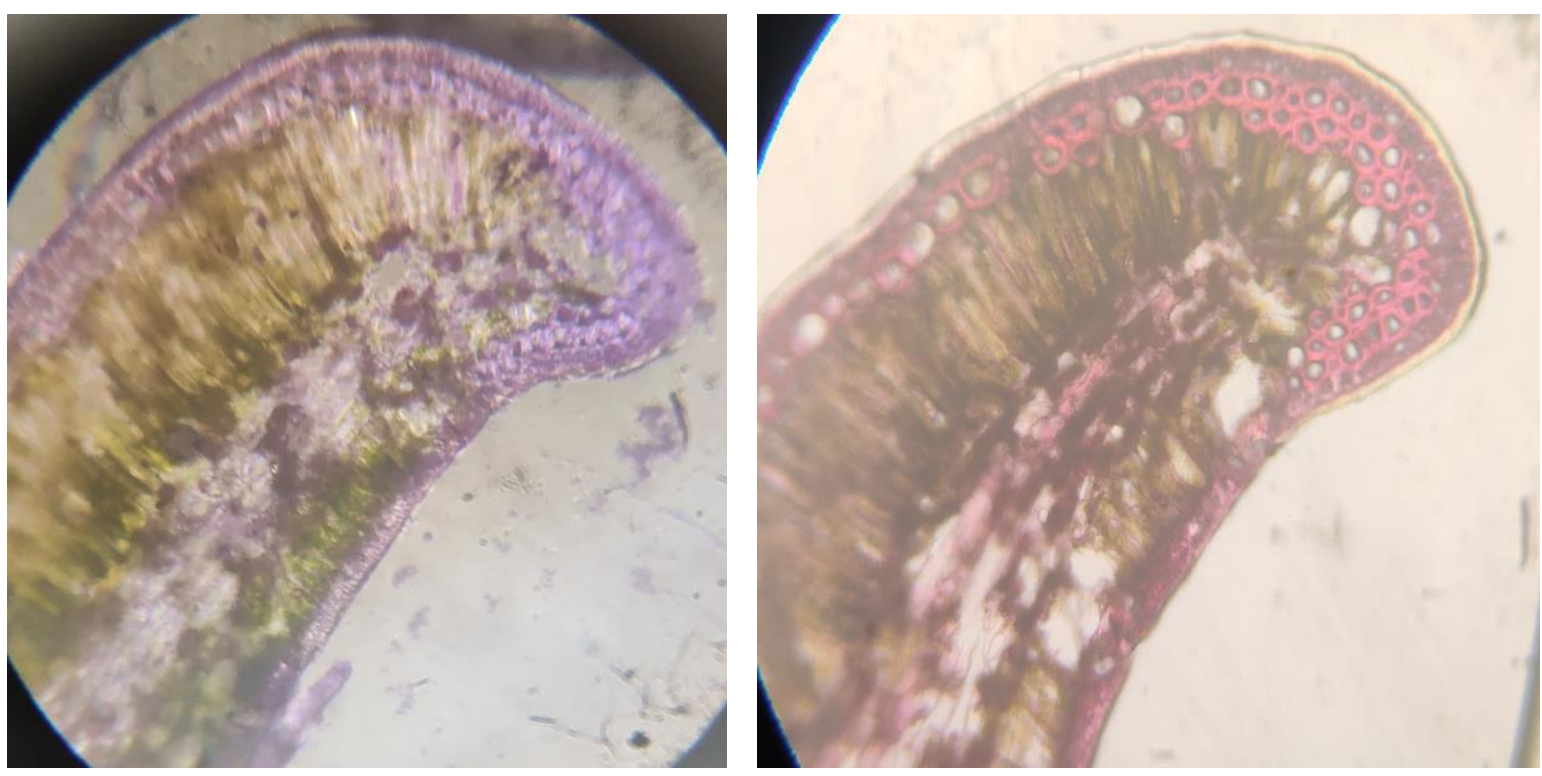

Figure 3: Histology of Cycas Circinalis Leaflet 


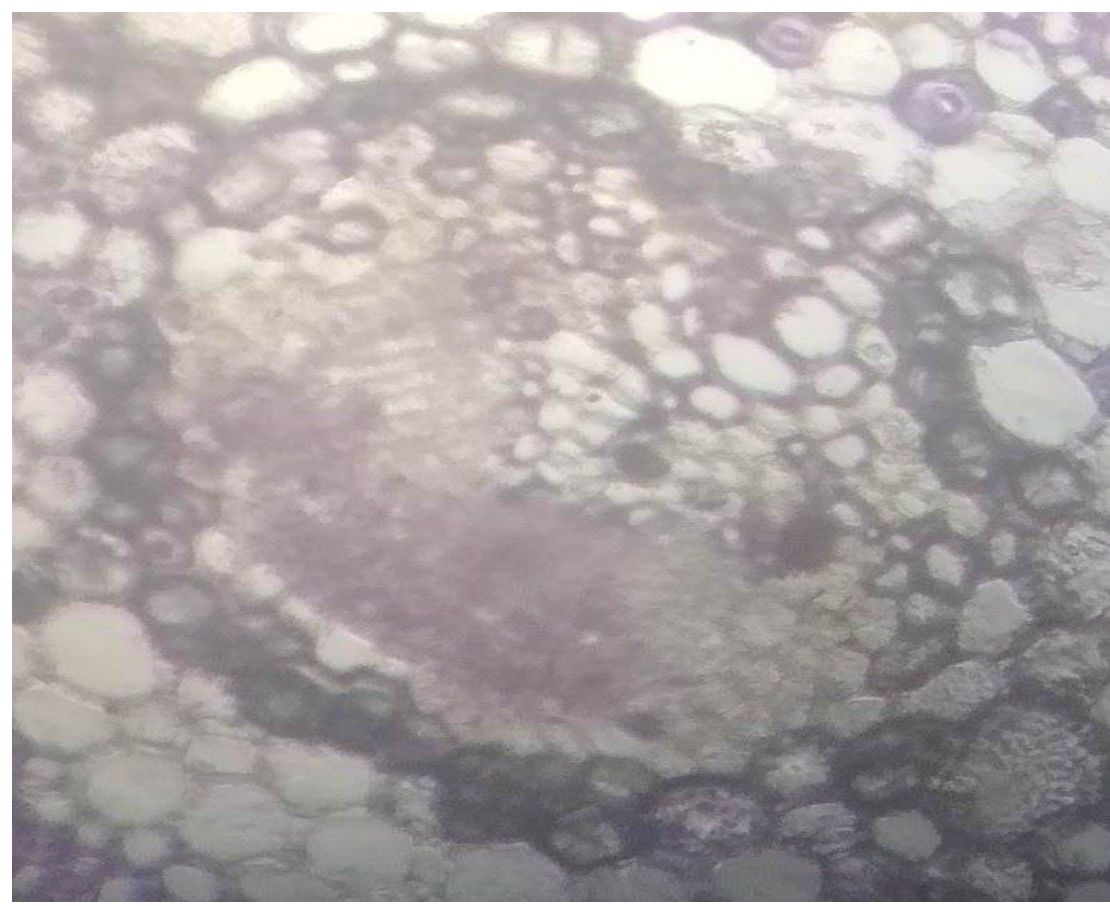

CYCAS CIRCINALIS

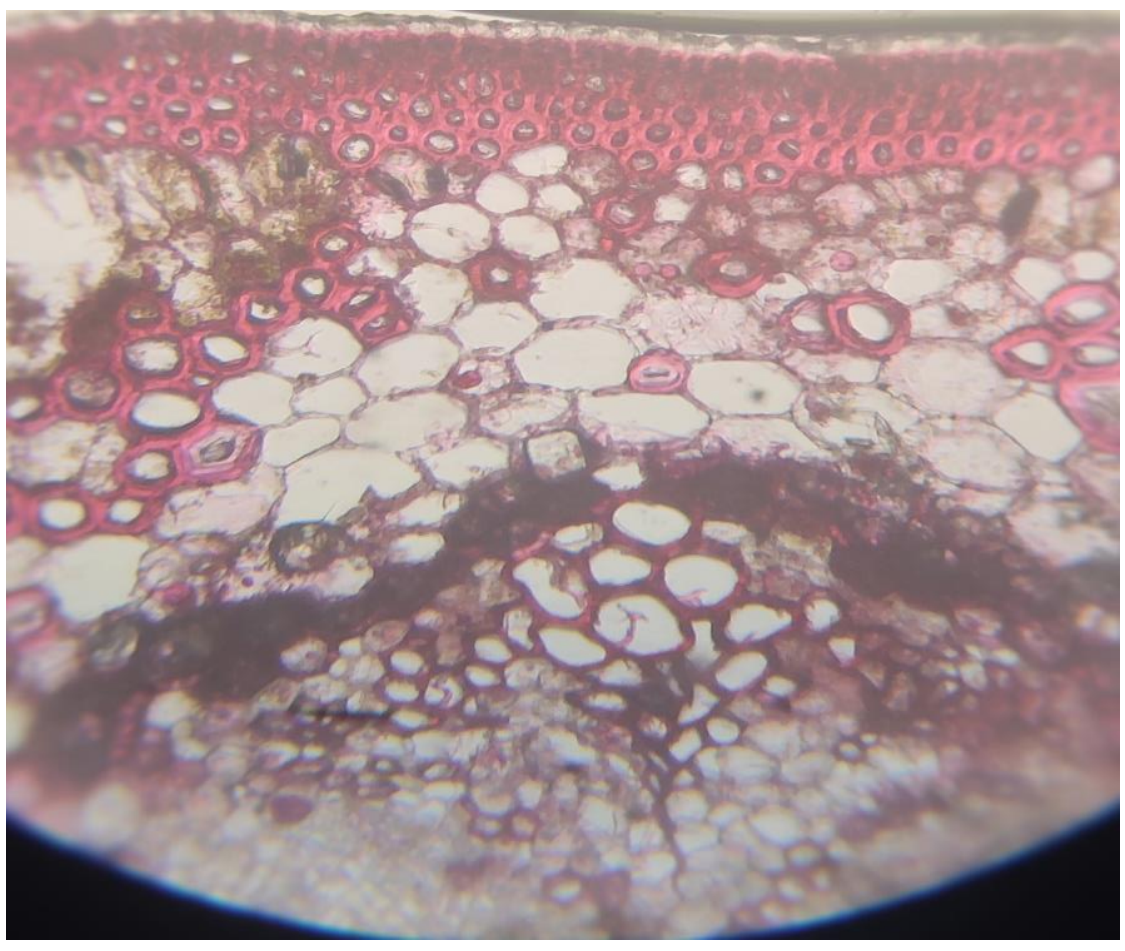

Figure 4: Vascular Bundle \& Cycas Revoluta 


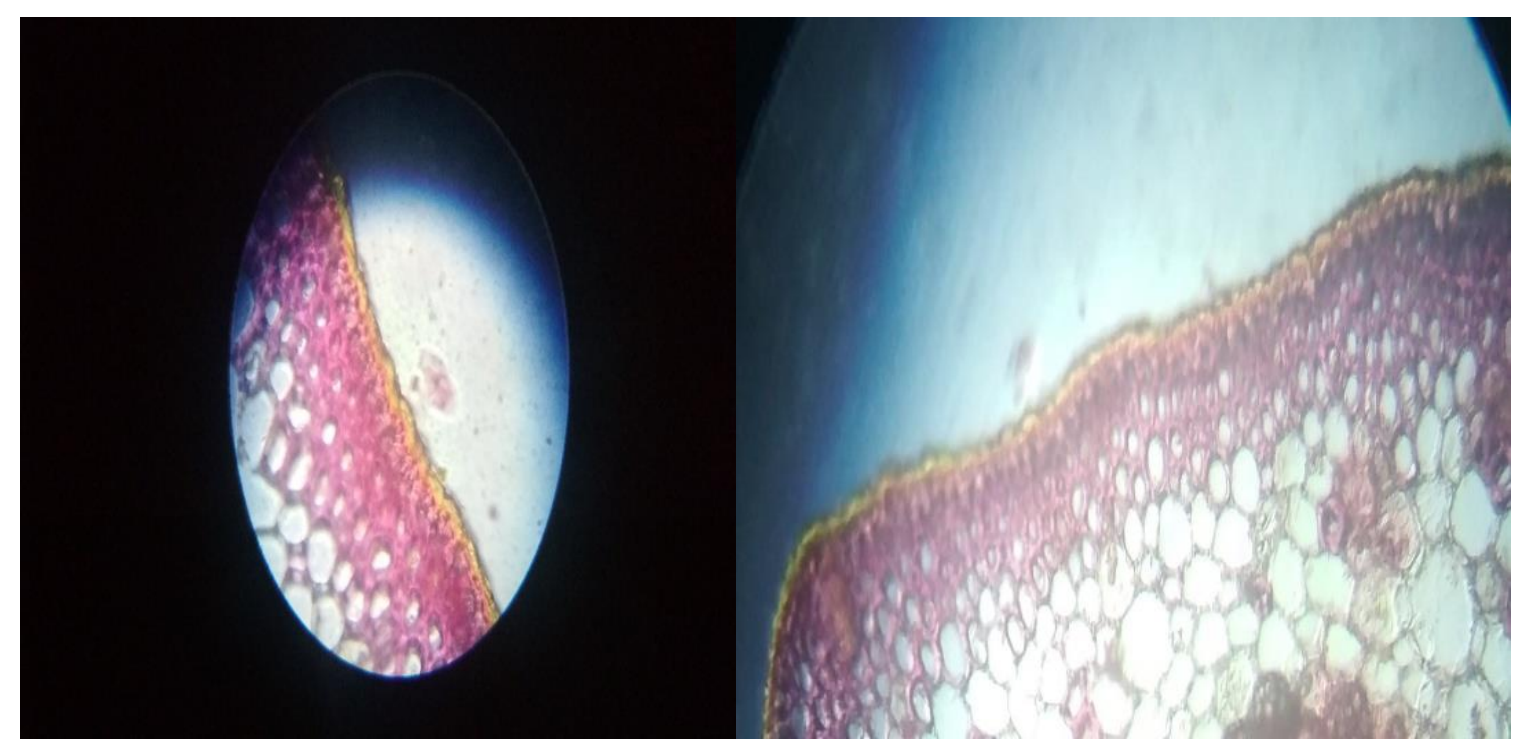

\section{CYCAS CIRCINALIS}
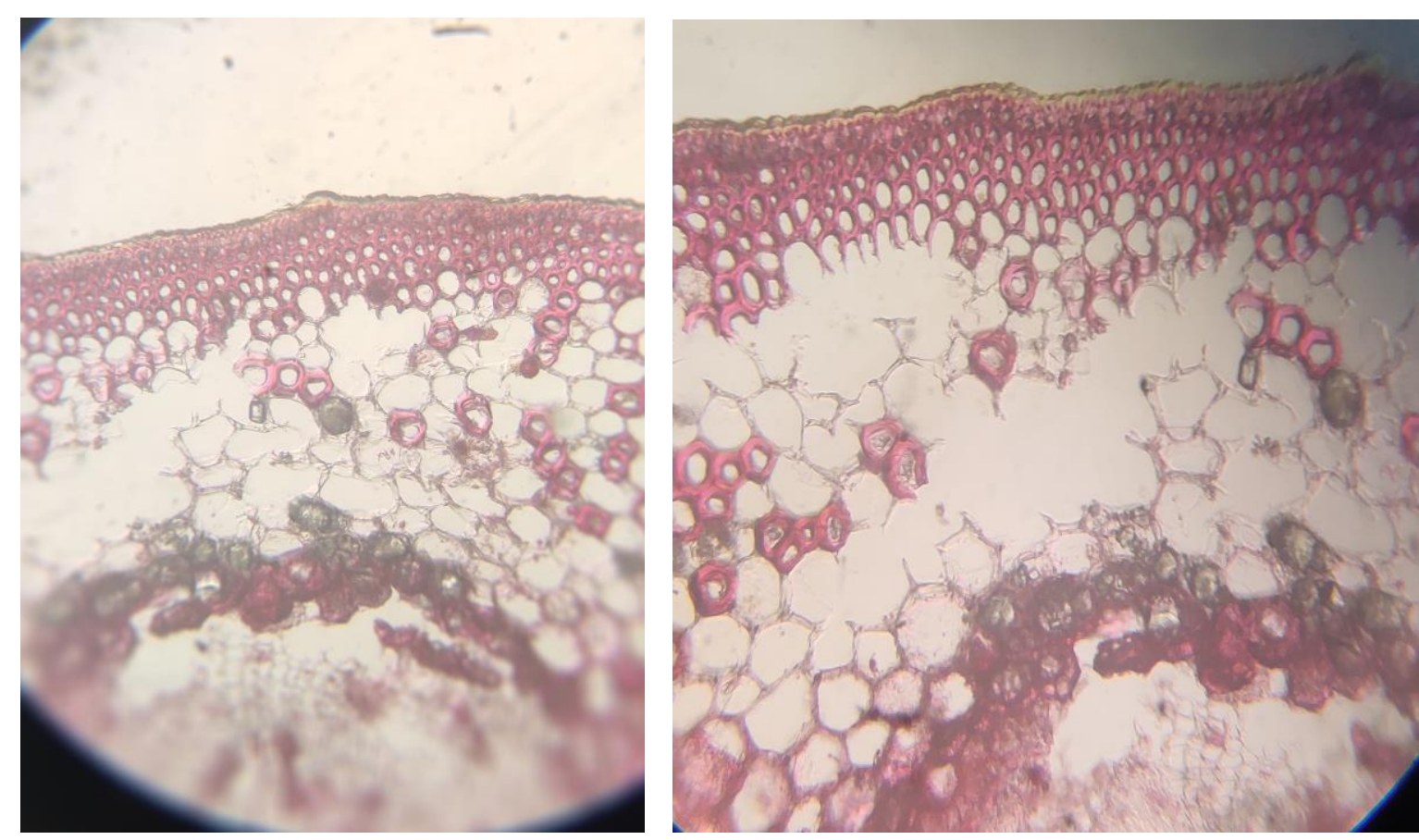

Figure 5: Epidermis with Cuticle 

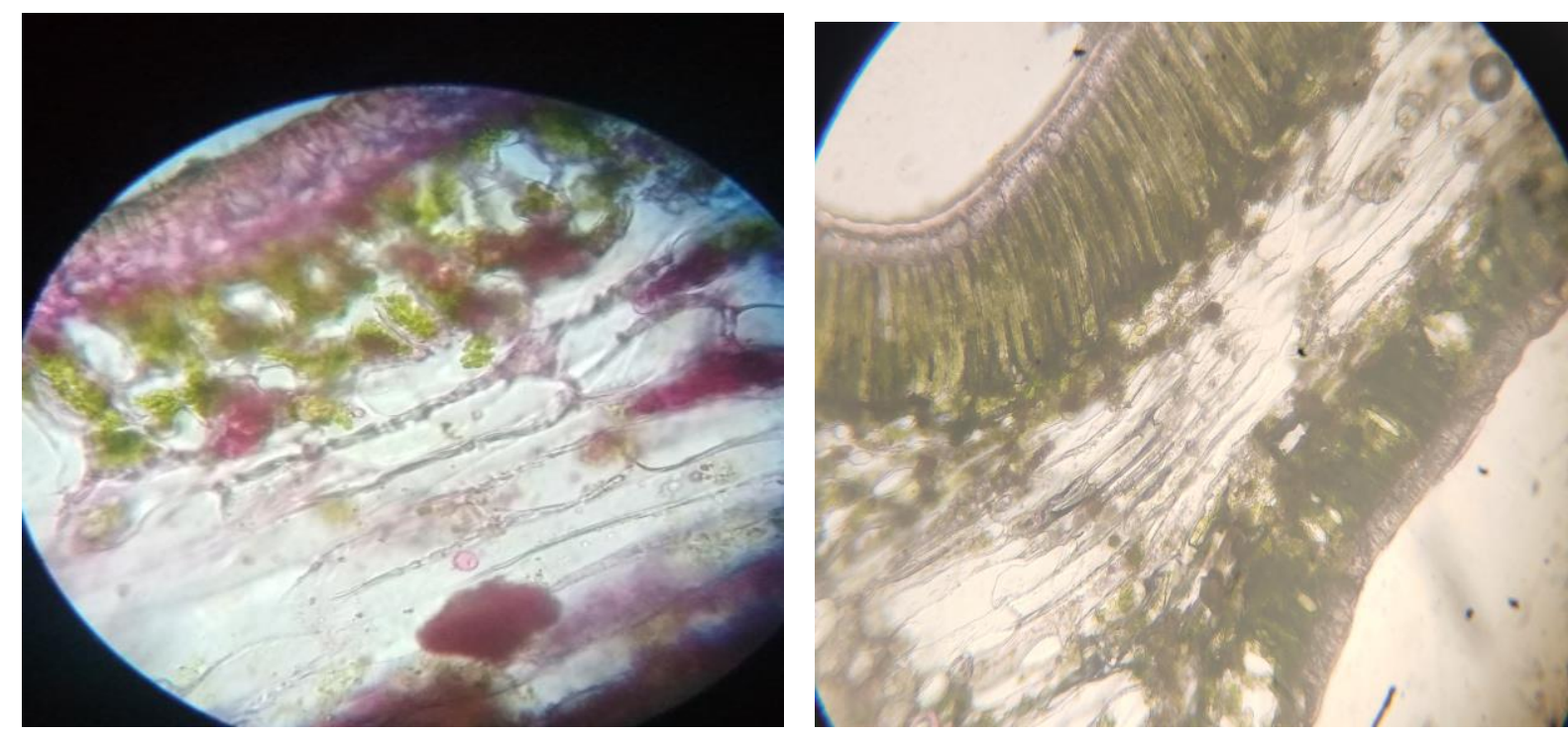

Figure 6: Transfusion Tissue Between the Mesophyll Tissue

\section{References}

AOAC. (1990). Official methods of analysis (16 ${ }^{\text {th }}$ ed.). Association of Official Analytical Chemists. Washington. D.C.

Botha, C.J., Naude, T.W., Swan, G.E. (1991). Suspected cycad (Cycas revoluta) intoxication in dogs. The Journal of the South African Veterinary Association.

Harborne, J.B. (1998). Phytochemical Methods. Chapman and Hall, London.

Knight, M.W., \& Dorman, D. (1997). Selected poisonous plant concerns small animals. Vet Med, 92(3), 260-272.

Kumar, S., Kumar, V., Selvaraj, V. R. (2013). Preliminary Phytochemical Screening of Cycas circinalis (1.) and Ionidium suffruticosum (ging.). International Journal of Pharmacy, 3(3), 510-513.

Lindstrom, A.J., \& Hill, K.D. (2007). The genus Cycas (Cycadaceae) in India. Telopea, 11, 463-488.

Manoj, K., Prakash, M.A., Swami, A., Singh, G.K., \& Mathur, A. (2011). Leaves of Cycas revoluta: Potent Antimicrobial and Antioxidant Agent. World Journal of Science and Technology, 1(10), 11-20.

Muller-Esneault, S. (2009). Cycas Revoluta: The Sago Palm, or Cycad Toxicity. Critterology.com.

Peach, K., \& Tracey, M.V. (1956). Modern methods of plant analysis. Volume 3, Springer Verlag, Berlin.

Sofowora, A. J. (1996). Research on medicinal plants and traditional medicine in Africa. Journal of Alternative and Complementary Medicine, 2(3), 365-372

Trease \& Evans. (1997). Pharmacognosy (14th Ed), Harcourt Brace and Company. Asia Pvt. Ltd. Singapore. 